\title{
Epidemiological Studies of the Chinese Hamster
}

\author{
F.L. Schmidt, L.G. Leslie, J.R. Schultz and G.C. Gerritsen \\ Diabetes Research, The Upjohn Company, Kalamazoo, Michigan, USA
}

\begin{abstract}
Summary. Records of 5832 animals from The Upjohn Company Chinese Hamster colony, for the period December 1966 to September 1969, have been collected and stored on a magnetic tape file. These data have been analyzed for onset of diabetes and longevity. - The time at which $50 \%$ of the animals became diabetic $(0 \mathrm{~T} 50)$ was 8.3 months during $1966 ; 4.3$ months during $1967 ; 2.6$ months during 1968; and 2.2 months during the first eight months of 1969. As time passed, the onset of diabetes became more uniform and predictable. Early in the colony history, onset of diabetes was quite variable, occurring from 2 to 31 months of age. Nondiabetics were not identified as such unless they were glucosuria-free for the first 15 months of age. It now appears that most animals which will become diabetic develop glucosuria by 5 months of age. This may permit earlier selection of nondiabetic control animals. Therefore, it may be possible to evaluate a variety of treatments on both onset of diabetes and longevity of the diabetic. - The longevity data show that, for the thirty-three month period of time studied, $50 \%$ of the total diabetic population were dead by 14.4 months of age. In contrast, 15 months of nonglucosuria was required to define an animal as nondiabetic. No significant difference was seen in the longevity of diabetics and nondiabetics surviving 15 months or longer.
\end{abstract}

Le diabète du Hamster chinois: Etudes épidémiologiques.

Résumé. Les résultats de l'étude portant sur 5832 animaux de la colonie de hamsters chinois de la «Upjohn Company", mis en observation entre décembre 1966 et septembre 1969 , ont été rassemblés et enregistrés sur bande magnétique. Ces données ont été analysées afin d'établir la date de l'apparition du diabète et la durée de vie des animaux. La manifestation du diabète, chez $50 \%$ des animaux (0T50), se situe à 8.3 mois en 1966 ; à 4.3 mois en 1967 ; à 2.6 mois en 1968 et à 2.2 mois pour les premiers huit mois de 1969. Avec le temps, l'apparition d'un diabète devient plus uniforme et mieux prévisible. Au début de l'histoire de cette colonie, le moment de la manifestation d'un diabète variait entre 3 et 31 mois. Les animaux non-diabétiques n'ont pas été considérés comme tels, sauf s'ils n'avaient pas de glycosurie pendant les $\mathbf{1 5}$ premiers mois de leur vie. Il semble maintenant que la plupart des animaux qui deviendront diabétiques développent une glycosurie avant le cinquième mois de vie. Ceci permettra une détection plus rapide des animaux témoins non-diabétiques. L'étude de l'effet de différents moyens thérapeutiques sur l'apparition du diabète et la durée de vie de l'animal diabétique serait done facilitée. - Les résultats de l'étude sur la durée de vie montrent que pendant les 33 mois de l'étude, $50 \%$ de toute la population diabétique est morte à l'âge de 14.4 mois. Par contre, 15 mois sans glycosurie sont nécessaires pour qu'un animal puisse être considéré comme non-diabétique. Aucune différence significative n'a été trouvée entre la durée de vie des animaux diabétiques et non-diabétiques qui atteignent l'âge de 15 mois ou plus.

Epidemiologische Studien beim chinesischen Hamster

Zusammenfassung. Sämtliche zwischen Dezember 1966 und September 1969 registrierten Angaben über 5832 chinesische Hamster der Upjohn Kolonie wurden auf Magnetband gespeichert und mittels eines Elektronenrechners in bezug auf den Zeitpunkt des Manifestwerdens des diabetischen Syndroms und die Lebensdauer analysiert. Während der Beobachtungsdauer sank das Alter in welchem bei $50 \%$ der Tiere ein manifester Diabetes festgestellt wurde, progressiv ab und betrug 1966 8.3 Monate, 1967 4.3 Monate, 1968 2.6 Monate und 2.2 Monate während der ersten 8 Monate des Jahres 1969. Parallel zu dieser Entwicklung verminderte sich die Streuung des Alters zum Zeitpunkt der ersten Diabetesmanifestation. Während anfänglich wegen der großen individuellen Schwankungen ein aglykosurisches Tier erst im Alter von 15 Monaten als nichtdiabetisch bezeichnet werden konnte, werden gegenwärtig die künftig diabetischen Tiere innerhalb der ersten 5 Lebensmonate glykosurisch. Dies sollte eine frühe Selektion diabetischer Tiere und damit die Beurteilung präventiver und therapeutischer Maßnahmen ermöglichen. Die Analyse des Sterbealters der innerhalb der 33 Monate umfassenden Untersuchungsperiode gestorbenen Tiere ergab, daß 50\% der diabetischen Population 14.4 Monate nicht überlebten. Da anfänglich nichtdiabetische Tiere erst im Alter von 15 Monaten als solche identifiziert werden können, ist es unmöglich, eine entsprechende Vergleichszahl für nichtdiabetische Tiere anzugeben. Wenn diabetische Tiere 15 Monate überlebt haben, entspricht ihre Lebenserwartung derjenigen der nichtdiabetischen Population.

Key-words: Diabetes in animals, chinese hamster, cricetulus griseus, epidemiology, onset of diabetes, age and diabetes, longevity and diabetes.
It is estimated that approximately eighty years would be required to complete a four-generation study of diabetes in man. It is not surprising then, that there is little reliable epidemiological information available regarding diabetes in man. The life span of the chinese hamster is one-twentieth that of man with the possibility of four generations per year. It has been reported that the inheritance pattern $[5,1]$ and many of the biological parameters of diabetes $[3,4]$ in the chinese hamster may be similar to those of man. Because of these considerations, the chinese hamster is a more convenient tool for the study of diabetes than man.
Before treatment to prevent or retard the onset of diabetes can be developed, some means must be found to identify those individuals destined to become diabetic. Controlled studies in man are virtually impossible. Carefully documented studies in the chinese hamster could well provide the information for such detection.

\section{Methods}

This paper presents the initial analysis of the records of The Upjohn Company chinese hamster co- 
lony. The data presented are an empirical study of the colony. A dynamic file of these records was created and maintained with the IBM System 360 F 30 computer. These data consist of birth records, death records, lineage and bimonthly urine glucose measurements of each colony animal. These data permit preliminary evaluation of onset of diabetes and of the effect of the latter on longevity. The data file contains records for the thirty-three month period, December 1966 to September 1969. The data consist of more than four hundred thousand bits of information about the colony animals.

The entire colony is maintained on Purina Mouse Breeder Chow ad libitum and under conditions described by Gerritsen [5]. Diabetics reported in this study are not treated. All animals are tested bimonthly for glucosuria. Freshly expressed urine is applied to Tes-Tape ${ }^{\circledR}$ strips and rated in accordance with the color chart provided with the strips.

With the exception of certain experimental matings, it is estimated that $95 \%$ of matings in the colony are brother $x$ sister and the remainder are father $x$ daughter. Mother $\times$ son matings have never been successful. Emphasis has been placed on mating diabetic to diabetic; however, diabetic to nondiabetic matings are used. Nondiabetic to nondiabetic matings are done for control purposes and to maintain the colony population.

Establishment of definitions was essential to any analysis of these data. It is recognized that upon further evaluation of data, these definitions may well be modified.

For this analysis, the following definitions have been established: a diabetic animal is defined as one which has two positive recorded urine glucose measurements by Tes-Tape ${ }^{\circledR}$, at any time during its life span. Both measurements must be rated two plus or greater. A nondiabetic is defined as an animal which has attained mals were found to become diabetic after the age of fifteen months.

Age at onset was determined by calculating the time interval from date of birth to the date of the first of the two positive Tes-Tape ${ }^{\circledR}$ records for each diabetic animal.

When the data file was analyzed on the basis of the definitions, it contained 5832 animals consisting of $17 \%$ diabetics and $43 \%$ nondiabetics. Forty percent of the animals in the data file did not fit either definition and, therefore, are not reported in this study. The present data file represents forty-nine sublines. Twentyeight of these lines have produced diabetics. The remainder have produced both nondiabetics and nondefinable animals.

Longevity studies were done only on animals which could be defined. Data on deaths of animals utilized for research purposes are not included in the longevity studies.

Because the records of the entire colony were surveyed, this study gives no consideration to genetic lines, crosses, degree of inbreeding, severity of diabetes, or sex differences.

The age of the animals when the first of the two required two plus Tes-Tape ${ }^{\circledR}$ readings was observed appeared to follow closely a log normal distribution. Accordingly, onset time fifty (OT 50) values were obtained from a logarithmic transformation of the data. The mean of the logarithms transformed back to the original scale estimates the age at which $50 \%$ of the animals became diabetic. Survival time fifty (ST 50) values, which are an estimate of the age at which $50 \%$ of the animals are dead, were obtained in the same manner.

\section{Results}

The scattergram presented in Figure 1 shows age at onset of diabetes of all diabetics in the colony.

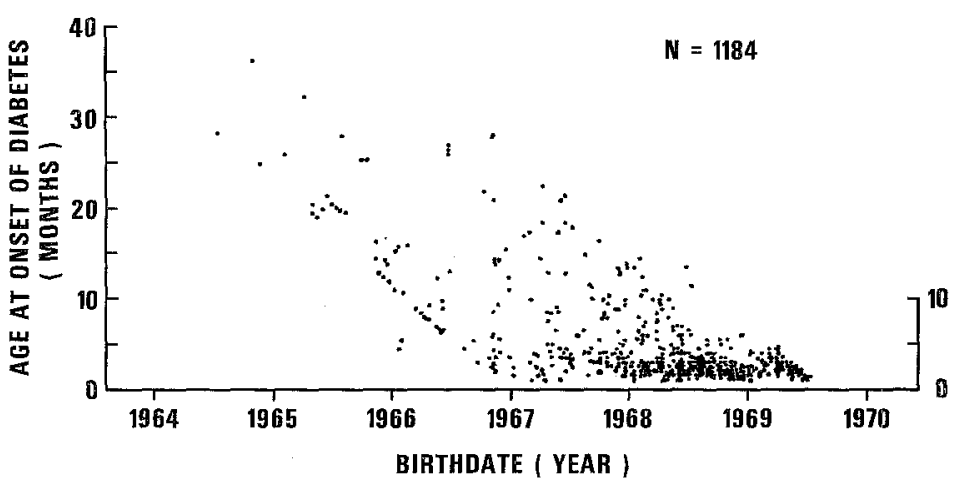

Fig. 1. Age at onset of diabetes in the chinese hamster colony

fifteen months of age and has no positive urine glucose measurements by Tes-Tape ${ }^{\circledR}$. This definition of nondiabetic was made in $\mathbf{1 9 6 7}$. It appeared to be a rea. sonable working definition at that time since few ani-
This scattergram was produced on an EAI Dataplotter and is an example of the kind of plot available for purposes of monitoring the colony production. The horizontal axis represents birthdate. The vertical axis 
represents age in months at onset of diabetes. Each point may represent one or more diabetic hamsters because multiple values at the same locus were superimposed. The first diabetic in the existing records was born in mid-1964 as shown on the horizontal axis. It was twenty-eight months old at onset of diabetes as shown on the vertical axis. Further, the most recently recorded birth in the colony occurred in the middle of 1969 and that hamster was two months of age at onset.

It can readily be seen from these data, that with the progression of time, an increasing number of diabetics was produced in the colony. Again, as time passed, these data show that greater numbers of hamsters developed diabetes at an increasingly early age. The earliest onset date to occur in the colony does not appear on this figure because it happened only very recently. That animal was 16 days old and not yet weaned. It can also be seen from these data that animals born during 1968 and 1969 develop glucosuria at a more uniform age and, therefore, may have a more predictable onset age. Considering only animals produced thus far in 1969 , it would appear that if they are to become diabetic, they will be glucosuric by five months of age or not at all.

Table 1 shows OT 50 values in months calculated from data presented in Fig. 1. Again, it is obvious that the onset time of diabetes has become less with time. For example, $50 \%$ of animals born in 1969 become diabetic at 2.2 months compared with 8.3 months in 1966. It is interesting to note that the upper limits of the range have also decreased from 31 months in 1966 to 5 months in 1969. The marked decrease in range again suggests that onset of diabetes in the colony may be approaching a predictable state.

Table 1. Onset time fifty (months) of diabetic chinese hamster colony

\begin{tabular}{lrlll}
\hline Year & \multicolumn{1}{c}{$\mathrm{N}$} & OT50 & $95 \%$ C. I. & Range \\
\hline 1966 & 74 & 8.3 & $7.0-9.7$ & $2.0-31.0$ \\
1967 & 194 & 4.3 & $2.9-4.8$ & $1.0-23.0$ \\
1968 & 634 & 2.6 & $2.5-2.7$ & $1.0-15.0$ \\
1969 & 269 & 2.2 & $2.1-2.3$ & $1.0-5.0$ \\
\hline
\end{tabular}

a C. $\mathbf{I} .=$ Confidence interval

Table 2. Survival time fifty (months) of diabetic and nondiabetic chinese hamsters

\begin{tabular}{llllll}
\hline & & Age & N & ST 50 & 95\% C.I. \\
\hline Diabetic & & all & 363 & 14.4 & $13.5-15.3$ \\
Diabetics & not $<$ & 15 mo. & $\mathbf{1 7 6}$ & 23.3 & $22.2-24.5$ \\
Nondiabetics & not $<$ & 15 mo. & 236 & $\mathbf{2 4 . 4}$ & $\mathbf{2 3 . 5}-25.0$ \\
\hline
\end{tabular}

a C. I. = Confidence interval

Table 2 shows calculated ST 50 values in months of diabetic and nondiabetic chinese hamsters. All defined. diabetics in the colony are included in the first line of the table. Fifty percent of the total diabetic group are dead at 14.4 months of age. This group cannot be compared with a nondiabetic group since by definition, nondiabetics must survive, glucosuria-free, for a minimum of 15 months.

It was possible, however, to compare diabetics with nondiabetics which survived 15 months or longer. This comparison is seen in lines 2 and 3 of this table, and represents only the surviving $50 \%$ of the total diabetic group. No significant difference between the ST 50's of the two long-lived groups is seen.

\section{Discussion}

Very little was known about diabetes in the chinese hamster at the time the colony was originated; therefore, any study of these records had to be done retrospectively. This retrospective approach, of course, has its limitations. However, the immediate value is the important baseline information which has been accumulated about the chinese hamster.

Owing to the uniformity and predictability shown in the recently produced diabetics, earlier selection of breeding stock is now possible. Since reproductivity of the female begins at three months of age and starts to decline at 7 months, this kind of information is very meaningful.

Perhaps the most stimulating aspect of the data presented is that they may be of considerable use in prospective studies. The success of any prospective study of diabetes in the chinese hamster is dependent on the ability to select, with some degree of certainty, the kind of animals to be used. Prior to analysis of the data presented in this paper, the definition of the nondiabetic animal resulted in serious limitations in experimental design of prospective studies. As an example, interpretation of the survival time data presented was very limited because of this lack of a nondiabetic control group of less than 15 months of age.

The onset data presented have shown that a uniform and predictable kind of hamster population can be produced. With this kind of production capability, redefinition of the nondiabetic is now possible. Since the recently produced diabetics become glucosuric by 5 months of age, the nondiabetics born during the same period of time may be redefined as glucosuriafree for 5 months rather than 15 . Redefinition would permit early selection of nondiabetic control groups for further studies of onset, severity, and longevity. Redefinition may permit well-controlled studies of various treatments which may influence longevity of the diabetic such as various diets, treatment with oral agents and insulin, and combinations of diet and therapy. A test system to detect new antidiabetic agents could be devised for use in a uniform and predictable hamster population.

The survival time data showing no significant difference in longevity of diabetics and nondiabetics which survived 15 months, suggest that diabetes did not affect their longevity. Because our data have no re- 
lation to severity of diabetes, we can only speculate that the diabetic population in this comparison probably consisted of the very mild type of diabetic. Using predictably diabetic and nondiabetic animals, studies designed to determine the value of dietary control could be initiated.

The increased predictability of animals in this colony provides a rationale for studies to evaluate therapy to prevent or retard the onset of diabetes. It may become possible to predict, with some degree of confidence, the percentage of newborn hamsters which will become diabetic and at what specific age they will become diabetic. This could lead to studies on the influence of diet and therapy on the retardation and/or possible prevention of clinical signs of diabetes such as carbohydrate intolerance and glucosuria.

The feasibility of studies designed to determine genetic markers of the prediabetic is also enhanced by such possible predictability. Animals from this colony may be useful for studies designed to detect the primary lesion of diabetes.

The possibility of rigidly controlled genetic studies is especially intriguing. Preliminary results suggest that breeding various combinations of diabetic and nondiabetic hamsters may result in offspring of predictable degrees of severity of diabetes [5]. In the future this may result in the differentiation and definition of the kinds of diabetes observed.

There is no certainty that the proposed studies discussed above would be applicable to man, however, previously reported work $[3]$ and genetic studies $[1,6]$ suggest that diabetes in the chinese hamster may be similar to that of man. The data presented may contribute to the insight and direction of future research. By use of animals from the Upjohn colony, and with redefinition of the nondiabetic and production of uniform and predictable diabetics, a variety of well-controlled experimental studies can now be initiated.

Acknowledgement. The authors gratefully acknowledge the valuable assistance and contributions of $\mathrm{Mr}$. L.B. Needham.

\section{References}

1. Butler, L.: The inheritance of diabetes in the Chinese hamster. Diabetologia 3, 124 - 129 (1967).

2. Gerritsen, G.C., Blanks, M.B.: Preliminary studies on food and water consumption of prediabetic Chinese hamsters. Diabetologia 6, 177-179 (1970)

3. - Dulin, W.E.: Characterization of diabetes in the Chinese hamster. Diabetologia 3, 74-84 (1967).

4. - - Serum proteins of Chinese hamsters and response of diabeties to tolbutamide and insulin. Diabetes $\mathbf{1 5}$, 331 (1966).

5. - Needham, L.B., Schmidt, F.L., Dulin, W.E.: Studies on the prediction and development of diabetes in offspring in diabetic Chinese hamsters. 29th Annual Meeting, American Diabetes Association, New York City, June 28-29, 1969.

6. Simpson, N.E.: Multifactorial inheritance: A possible hypothesis for diabetes. Diabetes 13, $462-468$ (1964).

F.L. Schmidt

Diabetes Research

The Upjohn Company

Kalamazoo, Michigan, USA 